\title{
SUPER- I MAKROSTRUKTURA POLSKICH, GRECKICH I CYPRYJSKICH AKTÓW NORMATYWNYCH. STUDIUM PORÓWNAWCZE W ASPEKCIE TRANSLATOLOGICZNYM
}

\author{
Karolina GORTYCH-MICHALAK, dr \\ Instytut Językoznawstwa, Uniwersytet im. Adama Mickiewicza w Poznaniu \\ al. Niepodległości 4, 61-874 Poznań \\ kmmgortych@gmail.com
}

\begin{abstract}
Abstrakt: Akty normatywne, w tym konstytucje i ustawy, są w polskim i greckim systemie prawnym, prymarnym źródłem prawa. Tymczasem w cypryjskim systemie prawnym są one, wraz z Konstytucja Republiki Cypru, ustawami zachowanymi na mocy artykułu 188 Konstytucji, zasadami prawa precedensowego (Common Law and Equity) i aktami prawnymi uchwalanymi przez Izbę Reprezentantów, jednym $\mathrm{z}$ wielu źródeł prawa $\mathrm{w}$ państwie. Wynika $\mathrm{z}$ tego, iż we wskazanych trzech państwach rola aktów normatywnych jest zróżnicowana. W związu z tym, struktura aktów normatywnych może być różna, choć są one dokumentami, gdzie zawarto przepisy regulujące daną sferę życia społecznego. Celem pracy jest porównanie struktury badanych aktów normatywnych pod kątem translatologii legilingwistycznej grecko-polskiej i polsko-greckiej. Analiza porównawcza poszczególnych części strukturalnych, czyli badanie ich cech wspólnych i różnic, ma za zadanie wypracowanie modelu aplikowanych badań porównawczych tekstów prawnych na potrzeby translatologii legilingwistycznej. Aplikacja modelu analizy porównawczej dostarcza wymiernych rezultatów na dwóch polach badawczych: i) zapewnienie ekwiwalentów translacyjnych dla terminologii tekstów prawnych i ii) zapewnienie ekwiwalentów translacyjnych dla terminologii danej dziedziny prawa, której dotyczą porównywane akty normatywne.
\end{abstract}

\section{SUPER- AND MACROSTRUCTURE OF POLISH, GREEK AND CYPRIOT NORMATIVE ACTS. A CONFRONTATIVE STUDY IN THE SCOPE OF TRANSLATION}

\begin{abstract}
Normative acts, together with the constitutions, are primary sources of law in the Polish and Greek legal systems. On the other hand, normative acts in the Cypriot legal system together with the Constitution of the Republic of Cyprus, the laws retained in force by virtue of Article 188 of the Constitution, the principles of Common Law and Equity, the laws enacted by the House of Representatives, are just some of the many sources of law in that state. Thus, in the three states mentioned above, the functions of the normative acts in question are different. With reference to this fact, the structures of normative acts are different too, although they are documents wherein rules regulating a certain domain of social life are drafted. The aim of this paper is to compare the structures of the normative acts analysed here in terms of Greek-Polish and Polish-Greek legal translation studies. The objective of comparing each structural element of the normative acts, and investigating their similarities and differences is to develop a model of applied contrastive analysis of legal texts for the purposes of legal translation studies. The application of this model of
\end{abstract}


contrastive analysis provides concrete results in two fields of research: i) providing translation equivalents for legal terms connected with legal textology and ii) providing translation equivalents for the area of law to which the texts compared belong.

Słowa kluczowe: Język prawny, superstruktura, makrostruktura, akt normatywny, przekład prawny

\section{Wstęp}

Studia porównawcze mają dla translatologii kluczowe znaczenie. Badania kontrastywne, a w szczególności stosowane badania kontrastywne, tworzą ramy dla porównywania języków, w tym ich jednostek, jakimi są teksty (Crystal 2008), na określone potrzeby, jak np. przekładoznawstwo (Kurtes 2006, 10, Fisiak 1981, 9).

W niniejszym artykule analizie porównawczej zostaną poddane teksty prawne, a dokładnie akty normatywne. Teksty prawne rozumiane sa jako teksty sporządzone w języku prawnym. Za uznaną w literaturze klasyfikacją Wróblewskiego przyjmuję, iż język prawny to język, w jakim są sformułowane teksty obowiązującego prawa (Malinowski 2006, 19), a co za tym idzie badane teksty prawne stanowią obowiązujace w Polsce, Grecji i na Cyprze akty normatywne. Materiał badawczy stanowią teksty konstytucji Rzeczpospolitej Polskiej, Republiki Grecji i Republiki Cypru oraz ustawy będące źródłem prawa cywilnego w Polsce, Grecji i na Cyprze, przy czym w Polsce i Grecji będą to odpowiednio kodeksy cywilne a w republice Cypru szereg ustaw regulujących określoną gałą́ prawa cywilnego -prawo spadkowe (ustawa 195 i powiązana z nią ustawa 189) (por. Neocleous 2000). W niniejszym opracowaniu porównywane teksty są tekstami paralelnymi, co zostanie wyjaśnione $\mathrm{w}$ dalszym ciągu pracy.

Celem analizy jest wskazanie różnic i podobieństw pomiędzy porównywanymi tekstami na poziomie makrostuktury i superstruktury tekstu. Wnioski płynące z analizy zostaną w dalszej kolejności zbadane pod kątem translatologii legilingwistycznej. $\mathrm{Z}$ ostatniego etapu badań wyłonione zostaną wnioski, które ukonstytuują model badań porównawczych aktów normatywnych na potrzeby translatologii legilingwistycznej.

\section{Pojęcia kluczowe}

Proponowaną w niniejszym artykule problematykę należy zilustrować pojęciami, które w różnych kontekstach mogą mieć pojęcie szersze, aniżeli użyte w niniejszym tekście. Z tego względu w niniejszej części opracowania zamieszczono definicje pojęć wykorzystywanych w opisie problemu.

Tekst aktu normatywnego $\mathrm{w}$ niniejszym opracowaniu rozumiany jest jako tekst sporządzony w języku prawnym. Jego funkcją jest stanowienie norm prawnych (Lizisowa 2009, 22) i ma charakter wypowiedzi dyrektywalnej, czyli takiej, która wskazuje adresatowi normy prawnej (wyrażonej językiem norm prawnych bezpośrednio lub językiem przepisów prawnych - pośrednio) określony sposób 
postępowania w określonych okolicznościach. (Wronkowska, Ziembiński 1997, 148). Zatem akt normatywny może być uznany za źródło prawa, z którego poznajemy treść prawa (Redelbach A. 1996, 108). Na potrzeby niniejszego artykułu istotną rolę będą odgrywały źródła prawa o charakterze ogólnokrajowym w Polsce, Grecji i na Cyprze, ponieważ kluczowym problemem jest analiza porównawcza tekstów aktów normatywnych $\mathrm{w}$ aspekcie translatologicznym polsko-greckim i grecko-polskim a wiec na poziomie języka prawnego całego państwa.

W polskim systemie prawny źródłami powszechnie obowiązującego prawa w ujęciu materialnym są: Konstytucja, ustawy, umowy międzynarodowe, prawo wspólnotowe i rozporządzenia (Korycki et al. 2006, 43-49). W greckim systemie prawnym za źródła powszechnie obowiązującego prawa w ujęciu materialnym uznaje się ustawę [nomos], w tym konstytucję [syntagma] jako ustawę zasadniczą (GrKC art. 1), prawo międzynarodowe i prawo wspólnotowe (Fefes 2004, 23-24). Z kolei w cypryjskim systemie prawnym źródłami powszechnie obowiązującego prawa w ujęciu materialnym są: konstytucja [syntagma], ustawy zachowane ma mocy artykułu 88 konstytucje, zasady prawa precedensowego (Common Law and Equity) i akty prawne uchwalone przez izbę Reprezentantów (Supreme Court of Cyprus ${ }^{1}$ 2007-2013). Spośród tych źródeł, na potrzeby badań poddane analizie zostaną akty normatywne o charakterze ustaw, tj. ustawy zasadnicze - konstytucja oraz teksty obowiązujących ustaw.

Język prawny, jakim sporządzono analizowane akty prawne, ma za zadanie realizowanie funkcji tekstu (por. Lizsowa 2006, 20), która, jak wskazano powyżej jest regulacja różnych sfer życia społecznego w formie norm prawnych o charakterze powszechnym (Moser \& Panaretou 2009, 1014). Z tego względu środki językowe języka prawnego będą realizowały również zadania poszczególnych elementów struktury aktu normatywnego, o których mowa w dalszej części artykułu.

Tekst aktu normatywnego, jak wspomniano powyżej ma funkcję dyrektywalną. Aby zrealizować zadanie, które stawia się tekstowi prawnemu, o jakich wspomniałam powyżej, musi on spełniać trzy podstawowe wymagania: precyzja, komunikatywność oraz wynikająca $\mathrm{z}$ nich adekwatność wypowiedzi do zamiaru prawodawcy. Tekst prawny wyraża adekwatnie intencje prawodawcy, jeśli jest dostatecznie precyzyjny w aspekcie obiektywnych reguł języka (por. Vlachopoulos 2008, 103). To właśnie precyzja, dokładność i poprawność językowa przyczyniają się do sformułowania tekstu adekwatnego. Tymczasem komunikatywność tekstu to zrozumiałość tekstu dla wszystkich osób nim zainteresowanych (Wronkowska, Zieliński 1997, 13-14).

Ponieważ przedmiotem zainteresowania jest superstruktura i makrostruktura tekstów normatywnych rozważania na temat język prawnego ograniczam do stwierdzenia, iż pełni on rolę ,służebną” w stosunku do funkcji tekstu aktu normatywnego i elementów jego struktury globalnej. Potwierdza to również Zieliński: „Język prawny przejawia się i realizuje się w konkretnych tekstach prawnych. Dlatego charakterystyka tego języka odbywać się będzie przez charakterystykę jego tekstów, z uwzględnieniem faktu, że teksty prawne są zawsze tekstami jakichś konkretnych aktów prawodawczych - ustaw, rozporządzeń albo uchwał" (Zieliński 1999, 50). Mam jednak świadomość, iż kwestia języka prawnego na poziomie mikrostruktur tekstowych, zdań, syntagm, wyrazów i in. (por. Matulewska 
2007, Kubacki 2008, Grzybek 2009, Gortych i Matulewska 2009, Kaczmarek 2011) jest tematem intensywnie eksplorowanym $\mathrm{w}$ ostatnim czasie, również $\mathrm{w}$ aspekcie translatologicznym.

Wskazane powyżej teksty mają kilka cech wspólnych a mianowicie: i) są źródłami powszechnie obowiązującego prawa na poziomie krajowym - czyli mają paralelną funkcję, ii) są sporządzone w języku prawnym (odpowiednio polskim i greckim) - paralelnym typie języka etnicznego, iii) dotyczą tych samych lub zbliżonych gałęzi prawa - maja paralelna tematykę. Wymienione podobieństwa kształtują wspólną platformę odniesienia niezbędna do przeprowadzenia badań porównawczych języka (Hoey and Haughton 2001, 46), którą można porównać do koncepcji tertium comparationis Krzeszowskiego (Krzeszowski 1990, 15-16). $\mathrm{Na}$ tej podstawie można uznać, iż analizowane teksty spełniają warunki, jakie w translatologii stawia się tekstom paralelnym a mianowicie stanowią: "a text that represents the same text type as the source text" (Delisle, 1999, 166), czy też stanowia "a text that treats the same or a closely related topic in the same subject field and that serves as a source for the $<$ mots justes $>$ and $<$ terms $>$ that should ideally be incorporated into the $<$ target text $>$ to ensure collocational <cohesion>" (Delisle,1999, 166). W niniejszym opracowaniu nie rozwijam kwestii innego typu tekstów paralelnych, jaki tworzą teksty źródłowe wraz ze swoimi przekładami (por. Matulewska 2010, 59).

Tekst paralelny w kontekście translatologii odgrywa istotną rolę. Potwierdza to Kierzkowska (por. Kierzkowska 2008), która rozwinęła teorię skoposu Vermeera mówiąca o kluczowej roli celu przekładu - skoposu. Vermeer stwierdził, iż każdemu tłumaczeniu winno przypisać się cel, który determinuje to, w jaki sposób tłumacz przekłada tekst dla danego odbiorcy (Vermeer 2003, 229-230). Kierzkowska w swoim modelu wprowadziła pojęcie imperatywu odbiorcy i wyróżniła trzy podstawowe typy odbiorców (Kierzkowska 2008, 88-89). Na potrzeby niniejszej analizy przyjmuje się, że odbiorca przekładu prawnego będzie odbiorca bliski, ponieważ jest on zaznajomiony z tematyka, kultura i okolicznościami powstania tekstu źródłowego i tekstu przekładu. Jest on jednocześnie najbardziej wymagającym odbiorca, ponieważ w przypadku przekładu tekstów prawnych, a dokładnie aktów normatywnych, oczekuje on, iż tekst przekładu będzie ekwiwalentny pod względem funkcji i stopnia sformalizowania z tekstem źródłowym. Aby tego dokonać należy stosować adekwatne rozwiazania translatorskie (Kielar 1988, 80), które prowadza, w przypadku przekładu tekstów specjalistycznych wg Kierzkowskiej (Kierzkowska 2008, 96) do uzyskania ekwiwalencji tekstowo-normatywnej. Kierzkowska wyjaśnia również, iż, aby tłumacz ją osiagną̧, winien stosować normy językowe i tekstowe właściwe dla danego tekstu, którym w niniejszym opracowaniu jest tekst aktu normatywnego. Orientacja na uzyskanie w tekście przekładu cech typowych dla danego typu tekstu sprawia, iż analiza porównawcza tekstów paralelnych jest konieczna, ponieważ to one są wiarygodnym źródłem wiedzy na temat struktury i cech tekstu na różnych jego poziomach i w różnych jednostkach, o czym pisze Neubert (1996, 101): „parallel texts are texts produced by users of different languages under near-identical communicative conditions. (...) Parallel text files (...)] are part and parcel of the material and mental equipment of the competent translator. This equipment is a vast database storing enormous experience. It is the key to 
an extensive knowledge of how texts are structured in the (text) world of different (communicative) cultures". Zapewnianie ekwiwalencji różnych jednostek językowych w oparciu o teksty paralelne winno być zorientowane na język docelowy, również w procesie przekładu tekstów prawnych (Pieńkos 1999, 182), dlatego też tak wielu badaczy, do których zalicza się autorka niniejszego tekstu, podkreśla istotna rolę znajomości i umiejętności eksploracji tekstów paralelnych.

Analizowane w niniejszym artykule teksty normatywne należą do jednego gatunku tekstów prawnych, a mianowicie do gatunku aktów normatywnych Takie teksty charakteryzują się stałymi cechami, do których należy struktura tekstowa (JopekBosiacka 2006, 138). Zarówno konstytucje, jak i ustawy zostaną porównane z punktu widzenia superstruktury, jak i makrostruktury, które rozumie się w niniejszym opracowaniu zgodnie z twierdzeniami van Dijka: „Superstructures have been defined as conventionalized schemata, which provide the global "form" for the macrostructural "content" of a text. Superstructures consist of hierarchical sequences of categories" (van Dijk 1980, 127). Z twierdzeniem van Dijka zgadza się również badaczka polskiego języka prawnego Lizisowa, która stwierdza, iż „Tekst prawny (...) jest (...) bowiem realizacją określonego schematu ujmowanego jako globalny model tekstu, czyli superstruktura” (Lizisowa 2006, 32) oraz, że „Struktura głęboka stanowi logiczny plan tekstu (makrostrukturę) obejmująca pewien rodzaj zagęszczenia tekstu do jego podstawowego przesłania" (Lizisowa 2006, 34).

Na podstawie przyjętych twierdzeń na potrzeby procesu analizy porównawczej opisanych powyżej tekstów paralelnych przyjmuje się założenie, iż superstruktura tekstu jest schematem formalnym organizującym treść tekstu na skalę globalną. Z kolei treść tekstu jest uporządkowana zgodnie z planem logicznym - makrostruktura.

Struktura tekstów prawnych $\mathrm{w}$ ujęciu teorii prawa może być również podzielona dwustopniowo na: 1) elementy makrokompozycji (tzw. duże części) oraz ii) elementy mikrokompozycji (małe, podstawowe jednostki) (Malinowski, 2006, 182). Jednak ten podział ma charakter niezwykle ogólny i nie odgrywa znaczącej roli w prowadzonych przez autorkę artykułu badań, która stawia sobie za cel analizę struktur tekstu aktu normatywnego $\mathrm{w}$ aspekcie translatologicznym.

\section{Metoda badawcza}

\section{Wybór materiału badawczego}

Pierwszym etapem podejmowanej $\mathrm{w}$ niniejszym opracowaniu analizy porównawczej jest wybór tekstów paralelnych, które, jak wspomniano powyżej spełniają określone wymogi. Jak wspomniano na wstępie niniejszego artykułu analizie zostaną poddane akty normatywne pochodzące z trzech państw: Cypru, Grecji i Polski. Odnalezienie wspólnych cech tekstów normatywnych jest w tym przypadku nieco utrudnione, ponieważ Polska i Grecja należą do państw, w których panuje system prawa stanowionego, podczas gdy na Cyprze stosuje się prawo precedensowe oparte na systemie brytyjskim, które jednak próbuje się skodyfikować. Doskonałym przykładem kodyfikacji prawa common law na Cyprze jest obszerna konstytucja 
będąca bardzo specyficzną na skalę całego systemu prawa stanowionego (Neocleous 2000, 16). Trudnością z translatologicznego punktu widzenia jest konieczność uwzględnienia różnic między greckim językiem prawnym a cypryjskim językiem prawnym (Vlachopoulos 2008. 108).

Istnienie konstytucji i uznawanie jej za najwyższy w hierarchii akt normatywny we wszystkich trzech państwach ${ }^{62}$ staje się głównym kryterium doboru tekstów poddanych analizie porównawczej pod kątem ich superstruktury i makrostruktury.

Kolejnymi aktami normatywnymi poddanymi takiej samej analizie porównawczej będą kodeks cywilny polski i grecki, ze szczególnym uwzględnieniem części dotyczącej prawa spadkowego. Ponieważ w cypryjskim systemie prawnym nie istnieją ustawy typu kodeks, na potrzeby badań wybrano dwie główne ustawy regulujące prawo spadkowe na Cyprze, czyli ustawę o testamentach i dziedziczeniu KEF195 i ustawę o zarządzaniu spadkiem osoby zmarłej KEF189 ${ }^{63}$. W tym wypadku wspólną płaszczyzną analizowanych aktów normatywnych stałą się gałąź prawa, a dokładniej prawo cywilne. Taki wybór sprawia, iż prowadzone badania na poziomie superstruktury i makrostruktury tekstów mogą być w dalszej perspektywie rozwijane na potrzeby przekładu prawnego polsko-greckiego i grecko-polskiego, o czym mowa będzie w podsumowaniu badań.

Teksty poddane analizie zostały wybrane na podstawie wspólnego kryterium, jakim jest ich obecność i rola w cypryjskim, greckim i polskim systemie prawnym.

\section{Proces badawczy}

Analiza porównawcza zostanie przeprowadzona w dwóch etapach. W pierwszym etapie zostaną wyodrębnione i porównane pod kątem obecności i nazewnictwa w analizowanych aktach normatywnych elementy superstruktury tekstu, jakimi są w części nieartykułowanej aktu normatywnego: tytuł, preambuła, określenie podstawy prawnej oraz w części artykułowane jednostki systematyzujące tekst aktów normatywnych: księga, tytuł, część, dział/rozdział, oddział, artykuł, ustęp / paragraf, punkt, litera, tiret

W drugim etapie badań zostaną wyodrębnione elementy makrostruktury tekstów normatywnych takie, jak: i) tytuł, ii) przepisy ogólne i szczegółowe, iii) przepisy o zmianie przepisów obowiązujących, iv) przepisy przejściowe i dostosowujące, v) przepisy uchylające, przepisy o wejściu ustawy w życie praz przepisy o wygaśnięciu mocy obowiązującej ustawy (przepisy końcowe) (Wronkowska, Zieliński 1997, 28-29) oraz vi) załączniki. Podczas analizy porównawczej elementy makrostruktury zostaną opisane pod kątem ich umiejscowienia $w$ teście, opatrzone opisem treści $\mathrm{i}$ zbadane pod kątem elementów superstruktury tekstu, aby wskazać łączność elementów struktury tekstowej.

\footnotetext{
${ }^{62} \mathrm{Na}$ potrzeby badań wprowadza się odpowiednie skróty: CyK - Konstytucja Republiki Cypru, GrK - Konstytucja Republiki Grecji, K - Konstytucja Rzeczpospolitej Polskiej, które pojawiają się w ybarnych miejsach.

${ }^{63} \mathrm{Na}$ potrzeby badań wprowadza się odpowiednie skróty: GrKC - grecki kodeks cywilny, KC polski kodeks cywilny, KEF189 - cypryjska ustawa o zarządzaniu spadkiem osoby zmarłej, KEF195 - cypryjska ustawa o testamentach i dziedziczeniu, które pojawiają się w wybranych miejsach.
} 


\section{Podsumowanie badań}

Podsumowanie badań zostanie przeprowadzone analogicznie do etapów badań, co oznacza, iż po każdym etapie badań zostaną wysunięte wnioski. Ostateczne wyniki badań będą przedstawione $\mathrm{w}$ kontekście translatologii legilingwistycznej, a w szczególności w aspekcie zakładanej przez autorkę przydatności analizy porównawczej tekstów paralelnych na potrzeby teorii przekładu. Na tym etapie autorka podejmie również próbę ukonstytuowania modelu badań porównawczych tekstów paralelnych, jakimi są akty normatywne, na poziomie superstruktury i makrostruktury w aspekcie translatologicznym.

\section{Analiza porównawcza}

\section{i) Analiza superstruktury.}

Proces porównania superstruktury badanych aktów normatywnych zostanie ujęty tabelarycznie, aby zobrazować podobieństwa i różnice tekstów pod kątem poszczególnych kryteriów.

\section{a) Analiza superstruktury tekstów konstytucji.}

Tabela 1: Porównanie elementów superstruktury konstytucji.

\begin{tabular}{|c|c|c|c|}
\hline $\begin{array}{l}\text { Zakładane elementy } \\
\text { superstruktury } \\
\text { tekstów Konstytucji }\end{array}$ & $\begin{array}{c}\text { Konstytucja } \\
\text { Rzeczpospolitej } \\
\text { Polskiej }\end{array}$ & Konstytucja Grecji & $\begin{array}{l}\text { Konstytucja } \\
\text { Republiki } \\
\text { Cypryjskiej } \\
\end{array}$ \\
\hline Tytuł aktu & $\begin{array}{l}\text { Tytul: Konstytucja } \\
\text { Rzeczpospolitej } \\
\text { Polskiej }\end{array}$ & 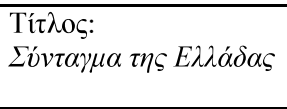 & 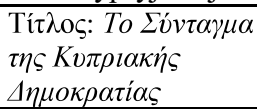 \\
\hline Preambuła & Preambuła $^{64}$ & $\Pi^{2}$ & \\
\hline Część & & Mépos & Mépos \\
\hline Dział/Rozdział & Rozdział & 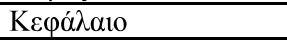 & 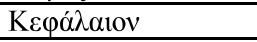 \\
\hline Oddział & & 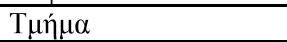 & \\
\hline Artykuł & Artykuł & $A \rho \theta \rho o$ & А $\rho \theta \rho o$ \\
\hline Ustęp/paragraf & Cyfra arabska np. 1. & Cyfra arabska np. 1. W & Cyfra arabska np. 1. \\
\hline \multicolumn{4}{|l|}{ Punkt } \\
\hline Litera & & $\begin{array}{l}\text { Litera alfabetu } \\
\text { greckiego np. } \alpha \text { ) }\end{array}$ & $\begin{array}{l}\text { Litera alfabetu } \\
\text { greckiego np. } \alpha)\end{array}$ \\
\hline Tiret & & & \\
\hline
\end{tabular}

${ }^{64}$ Ze względu na obszerność tekstu preambuły Konstytucji RP odwołuję czytelnika do tekstu źródłowego.

${ }^{65}$ Ze względu na obszerność tekstu preambuły Konstytucji RP odwołuję czytelnika do tekstu źródłowego. 


\section{b) Analiza superstruktury tekstów ustaw.}

Tabela 2: Porównanie elementów superstruktury ustaw.

\begin{tabular}{|c|c|c|c|}
\hline $\begin{array}{c}\text { Zakładane } \\
\text { elementy } \\
\text { superstruktury } \\
\text { tekstów ustaw }\end{array}$ & Polski kodeks cywilny & Grecki kodeks cywilny & $\begin{array}{c}\text { Cypryjska ustawa o } \\
\text { zarządzaniu spadkiem osoby } \\
\text { zmarłej, KEF } 195 \text { i cypryjska } \\
\text { ustawa o testamentach i } \\
\text { dziedziczeniu, KEF } 189 .\end{array}$ \\
\hline Tytuł aktu & $\begin{array}{l}\text { Tytuł: USTAWA z dnia } 23 \\
\text { kwietnia } 1964 \text { r. Kodeks } \\
\text { cywilny }\end{array}$ & 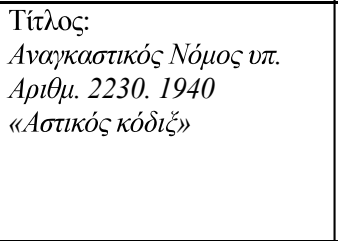 & 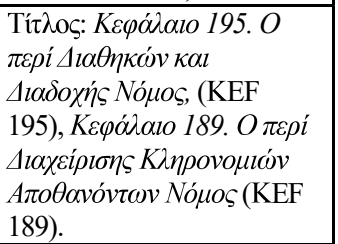 \\
\hline Preambuła & & 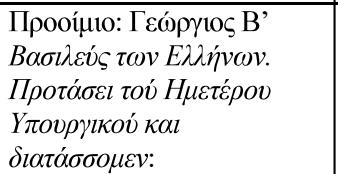 & \\
\hline $\begin{array}{l}\text { Określenie } \\
\text { podstawy } \\
\text { prawnej }\end{array}$ & & & $\begin{array}{l}\text { Opcjonalnie podanie } \\
\text { podstawy prawnej } \\
\text { sporządzenia tekstu w } \\
\text { języku greckim (KEF 195). }\end{array}$ \\
\hline Spis treści & & & 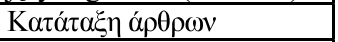 \\
\hline Księga & $\begin{array}{l}\text { Księga i tytuł księgi np. Księg } \\
\text { pierwsza. Czéśc ogólna. }\end{array}$ & 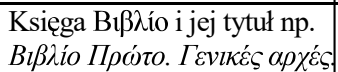 & \\
\hline Część & & & 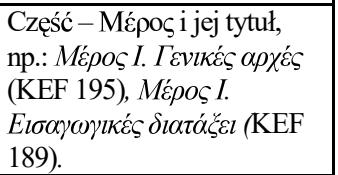 \\
\hline Tytuł & $\begin{array}{l}\text { Tytuł i jego nazwa: np. } \\
\text { Tytut I. Przepisy Wstępne. }\end{array}$ & & \\
\hline Dział & $\begin{array}{l}\text { Dział i jego tytuł, np.: } \\
\text { Dziat I. Osoby fizyczne. }\end{array}$ & & \\
\hline Rozdział & $\begin{array}{l}\text { Rozdział i jego tytuł, np. } \\
\text { Rozdziat I. Zdolność } \\
\text { prawna i zdolność do } \\
\text { czynności prawnych }\end{array}$ & 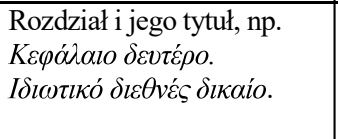 & \\
\hline \multicolumn{4}{|l|}{ Oddział } \\
\hline Artykuł & Artykuł i jego numeracja & 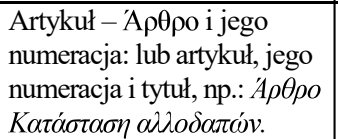 & 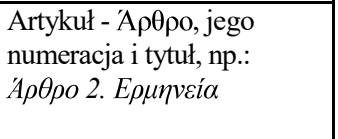 \\
\hline Ustęp / Paragraf & $\begin{array}{l}\text { Paragraf oznaczony } \\
\text { symbolem } \S \text { i opatrzony } \\
\text { numeracja. }\end{array}$ & & $\begin{array}{l}\text { Paragraf oznaczony } \\
\text { numeracja. }\end{array}$ \\
\hline \multicolumn{4}{|l|}{ Punkt } \\
\hline Litera & & & $\begin{array}{l}\text { Litera alfabetu greckiego } \\
\text { np. } \alpha \text { ). }\end{array}$ \\
\hline Tiret & & & \\
\hline
\end{tabular}




\section{c) Wnioski}

1. Analiza na poziomie superstruktury wskazuje różnice i podobieństwa pod kątem organizacji tekstu, jego jednostek, podziałów i nazw. W aspekcie translatologicznym jest niezwykle przydatna, ponieważ dostarcza konotatów formalno-tekstowych właściwych dla tekstów prawnych różnych systemów prawnych i państwowych, co wskazano $\mathrm{w}$ odpowiednich wierszach tabeli, np.: wiersz Tytut aktu, w którym wskazano greckie

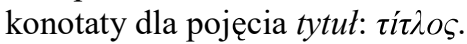

2. Przeprowadzona analiza tekstów na poziomie superstruktury wskazuje również problemy w odnajdowaniu właściwych konotatów. Doskonałym przykładem jest słowo $\kappa \varepsilon \varphi \alpha ́ \lambda \alpha l o$, które w przypadku przekładu z języka greckiego na język polski greckiego aktu normatywnego oznacza rozdziat por. tab. 2, wiersz Rozdziat). Jednak w przypadku

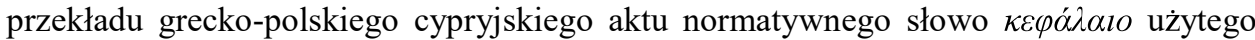
w tytule aktu normatywnego należałoby przetłumaczyć nie jako rozdział, ale raczej jako uchwała (Izby Reprezentantów), w szczególności, że występujące w tytule słowo vómos ma polski konotat ustawa utrwalony $\mathrm{w}$ przekładzie greckich i cypryjskich aktów normatywnych na język polski (por. Tab. 2. wiersz Tytuł aktu).

Powyższe rozważania sprowadzają się do stwierdzenia, iż przeprowadzona analiza porównawcza aktów normatywnych na poziomie superstruktury wskazuje problemy w procesie ustalania konotatów dla przekładu prawnego polsko-greckiego i grecko polskiego, ponieważ wskazuje na różnice pomiędzy greckim językiem prawnym i cypryjskim językiem prawnym na poziomie tekstowym. W procesie przekładu, kiedy należy podjąć decyzję o wyborze ekwiwalentu translacyjnego, odgrywa to kluczową rolę, o czym wspomniano powyżej powołując się na Vermeera i Kierzkowską. Jednocześnie przeprowadzona analiza jest źródłem gotowych i wiarygodnych rozwiązań translatorskich, o czym wspomniano w pierwszym wniosku płynącym z przeprowadzonej analizy. Wyodrębnione rozwiązania translatorskie, a dokładnie wskazane konotaty, moga mieć zastosowanie również w przekładzie prawniczym, np. w sytuacjach, kiedy w tekście prawniczym (np. umowa o pracę) przywołuję się odpowiednie akty normatywne.

\section{ii) Analiza makrostruktury.}

Proces porównania makrostruktury badanych aktów normatywnych zostanie ujęty tabelarycznie, aby zobrazować podobieństwa i różnice tekstów pod kątem poszczególnych kryteriów. 
a) Analiza makrostruktury tekstów konstytucji.

Tabela 3: Porównanie elementów makrostruktury konstytucji.

\begin{tabular}{|c|c|c|c|}
\hline $\begin{array}{l}\text { Zakładane } \\
\text { elementy } \\
\text { makrostrukt } \\
\text { ury tekstów } \\
\text { Konstytucji }\end{array}$ & $\begin{array}{c}\text { Konstytucja } \\
\text { Rzeczpospolitej Polskiej }\end{array}$ & Konstytucja Grecji & $\begin{array}{l}\text { Konstytucja Republiki } \\
\text { Cypryjskiej }\end{array}$ \\
\hline Tytuł & $\begin{array}{c}\text { Konstytucja } \\
\text { Rzeczpospolitej Polskiej }\end{array}$ & $\Sigma v ́ v \tau \alpha \gamma \mu \alpha \tau \eta \varsigma \mathrm{E} \lambda \lambda \alpha \dot{\alpha} \delta \varsigma \varsigma$ & 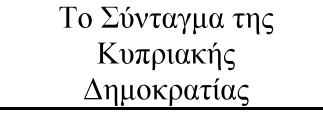 \\
\hline $\begin{array}{l}\text { Przepisy } \\
\text { ogólne i } \\
\text { szczegółowe }\end{array}$ & $\begin{array}{l}\text { Rozdział I (art. 1-29) } \\
\text { RZECZPOSPOLITA } \\
\text { Rozdział II (art. 30-86) } \\
\text { WOLNOSCI, PRAWA } \\
\text { I OBOWIAZKI } \\
\text { CZłOWIEKA I } \\
\text { OBYWATELA } \\
\text { Rozdział III (art. 87-94) } \\
\text { ŹRÓDłA PRAWA } \\
\text { Rozdział IV (art. 95- } \\
\text { 125) SEJM I SENAT } \\
\text { Rozdział V (art. 126- } \\
\text { 145) PREZYDENT } \\
\text { RZECZYPOSPOLITEJ } \\
\text { POLSKIEJ } \\
\text { Rozdział VI (art. 146- } \\
\text { 162) RADA } \\
\text { MINISTRÓW I } \\
\text { ADMINISTRACJA } \\
\text { RZACDOWA } \\
\text { Rozdział VII (art. 163- } \\
\text { 172) SAMORZĄD } \\
\text { TERYTORIALNY } \\
\text { Rozdział VIII (art. 173- } \\
\text { 201) SADY I } \\
\text { TRYBUNAŁY } \\
\text { Rozdział IX (art. 202- } \\
\text { 215) ORGANY } \\
\text { KONTROLI } \\
\text { PANSSTWOWEJ I } \\
\text { OCHRONY PRAWA } \\
\text { Rozdział X (art. 216- } \\
\text { 227) FINANSE } \\
\text { PUBLICZNE } \\
\text { Rozdział XI (art. 228- } \\
\text { 234) STANY }\end{array}$ & 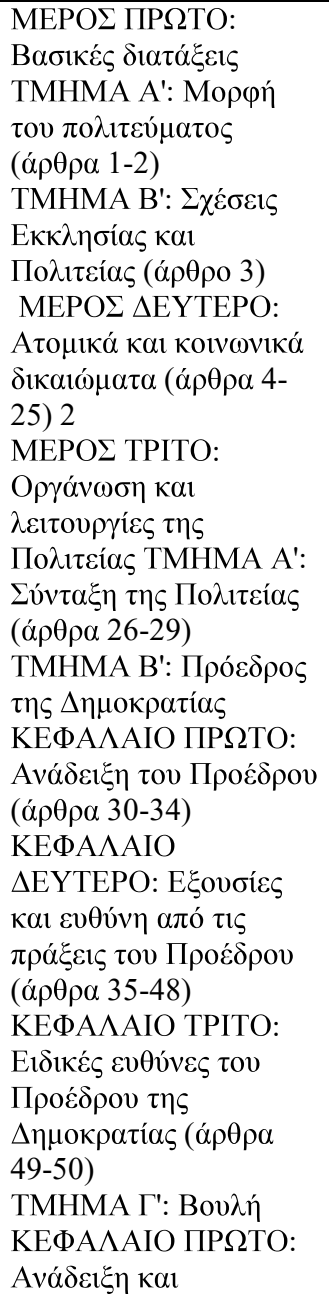 & 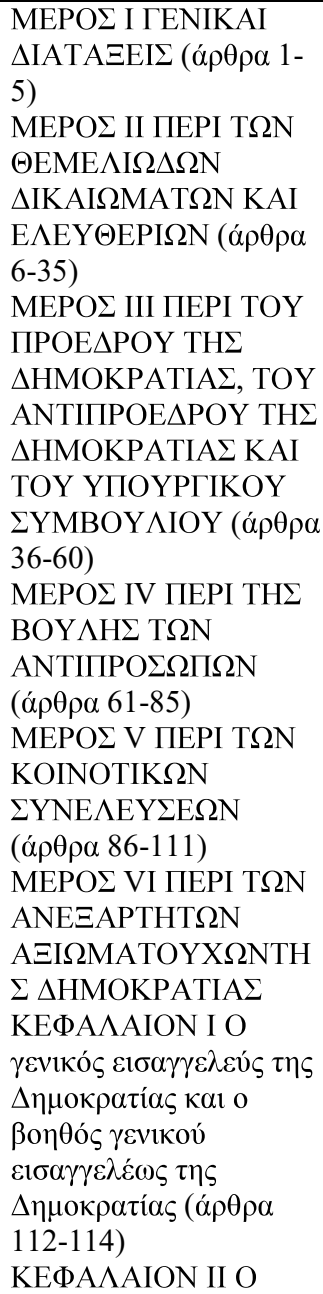 \\
\hline
\end{tabular}


Karolina GORTYCH-MICHALAK, Super-I Makrostruktura polskich, greckich...

\begin{tabular}{|c|c|c|}
\hline NADZWYCZAJNE & 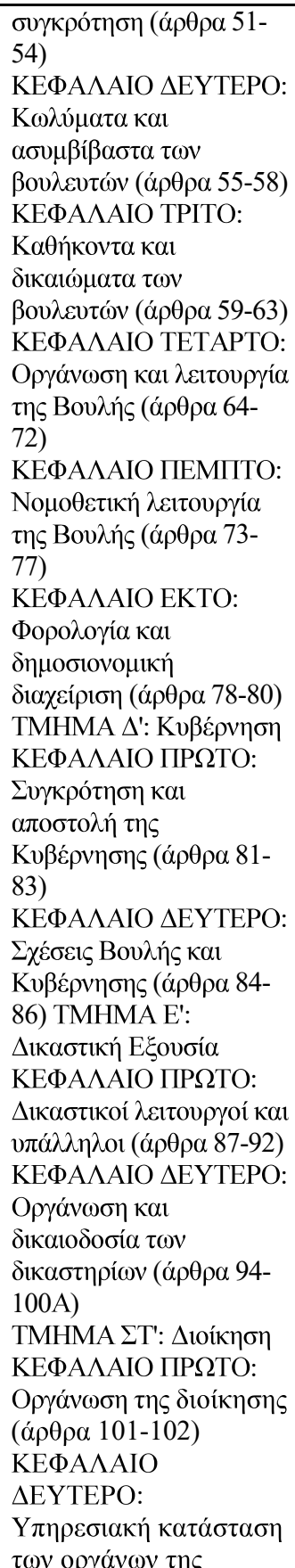 & 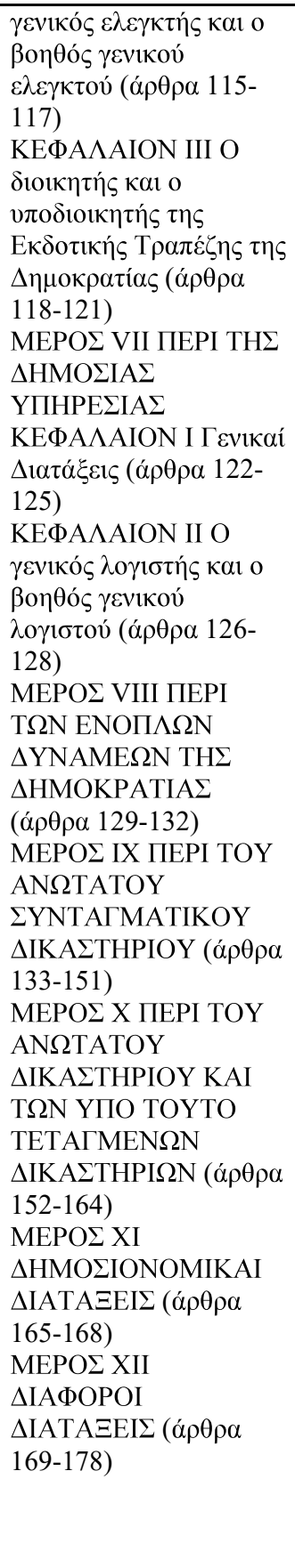 \\
\hline
\end{tabular}




\begin{tabular}{|c|c|c|c|}
\hline & & 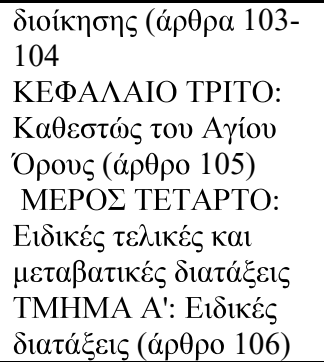 & \\
\hline $\begin{array}{l}\text { Przepisy o } \\
\text { zmianie } \\
\text { przepisów } \\
\text { obowiązując } \\
\text { ych }\end{array}$ & $\begin{array}{l}\text { Przepisy o zmianie } \\
\text { konstytucji zawarte w } \\
\text { Rozdziale XII (art. 235) }\end{array}$ & 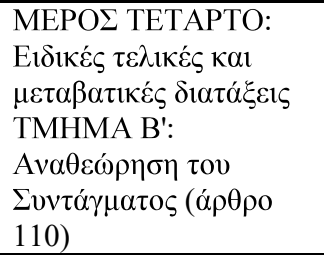 & \\
\hline $\begin{array}{l}\text { Przepisy } \\
\text { przejściowe i } \\
\text { dostosowuja } \\
\text { ce }\end{array}$ & $\begin{array}{l}\text { Przepisy przejściowe } \\
\text { zawarte w Rozdziale } \\
\text { XIII (art. 236-243) }\end{array}$ & 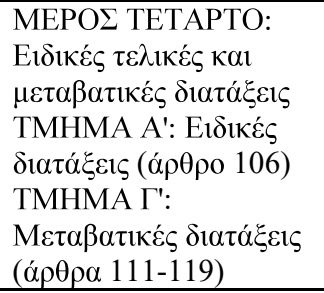 & 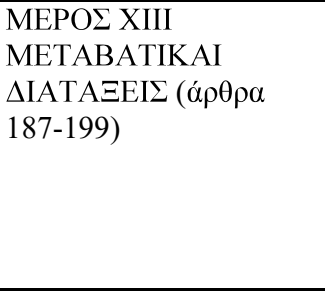 \\
\hline $\begin{array}{l}\text { Przepisy } \\
\text { uchylające, } \\
\text { przepisy o } \\
\text { wejściu } \\
\text { ustawy w } \\
\text { życie praz } \\
\text { przepisy o } \\
\text { wygaśnięciu } \\
\text { mocy } \\
\text { obowiązując } \\
\text { ej ustawy } \\
\text { (przepisy } \\
\text { końcowe) }\end{array}$ & $\begin{array}{l}\text { Przepisy końcowe } \\
\text { zawarte w Rozdziale } \\
\text { XIII (art. 236-243) }\end{array}$ & 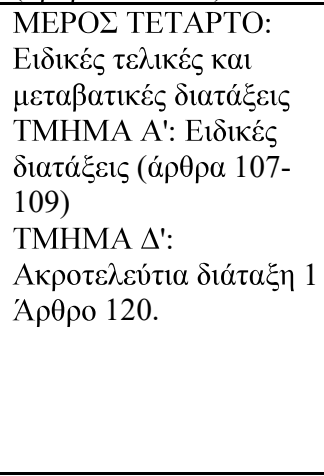 & $\begin{array}{l}\text { MEPO } \Sigma \text { XIII TE } \Lambda \text { IKAI } \\
\Delta \text { IATAEEI } \Sigma(\alpha \rho \rho \rho \alpha \\
179-186)\end{array}$ \\
\hline Załączniki & & & 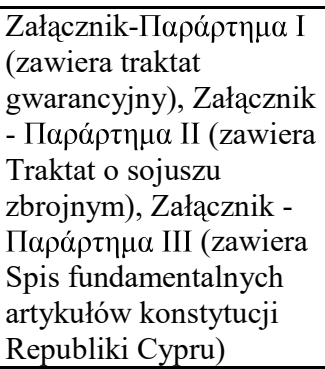 \\
\hline
\end{tabular}




\section{b) Analiza makrostruktury tekstów ustaw.}

Tabela 4: Porównanie elementów makrostruktury ustaw.

\begin{tabular}{|c|c|c|c|}
\hline $\begin{array}{c}\text { Zakładane } \\
\text { elementy } \\
\text { makrostruktury } \\
\text { tekstów } \\
\text { Konstytucji }\end{array}$ & $\begin{array}{l}\text { Polski kodeks } \\
\text { cywilny }\end{array}$ & $\begin{array}{l}\text { Grecki kodeks } \\
\text { cywilny }\end{array}$ & $\begin{array}{c}\text { Cypryjska ustawa o } \\
\text { zarządzaniu spadkiem } \\
\text { osoby zmarłej, KEF } 195 \text { i } \\
\text { cypryjska ustawa o } \\
\text { testamentach i } \\
\text { dziedziczeniu, KEF } 189 .\end{array}$ \\
\hline Tytuł & $\begin{array}{c}\text { Tytuł: USTAWA z } \\
\text { dnia } 23 \text { kwietnia } \\
1964 \text { r. Kodeks } \\
\text { cywilny }\end{array}$ & 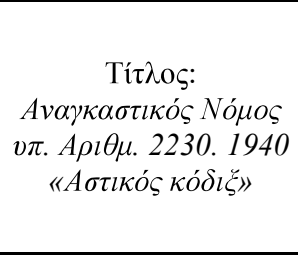 & 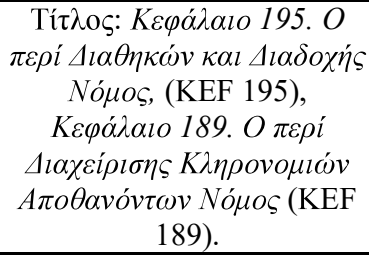 \\
\hline $\begin{array}{l}\text { Przepisy ogólne } \\
\text { i szczegółowe }\end{array}$ & $\begin{array}{l}\text { Przepisy ogólne } \\
\text { zawarte w księdze } \\
\text { (w pierwszych jej } \\
\text { artykułach) i } \\
\text { następujących } \\
\text { jednostkach } \\
\text { superstruktury } \\
\text { tekstu: Księga, } \\
\text { Tytuł } \\
\text { Dział, Rozdział, } \\
\text { Artykuł, Paragraf,. } \\
\text { Przepisy } \\
\text { szczegółowe } \\
\text { zawarte w } \\
\text { zorganizowane w } \\
\text { następujących } \\
\text { jednostkach } \\
\text { superstruktury } \\
\text { tekstu: Księga, } \\
\text { Tytuł } \\
\text { Dział, Rozdział, } \\
\text { Artykuł, Paragraf, } \\
\text { np.: } \\
\text { KSIĘGA } \\
\text { CZWARTA } \\
\text { SPADKI (Art. 922- } \\
\text { 1088) } \\
\text { Tytuł I. Przepisy } \\
\text { ogólne (art. 922- } \\
\text { 930) } \\
\text { Tytuł II. } \\
\text { Dziedziczenie } \\
\text { ustawowe (art. 931- }\end{array}$ & 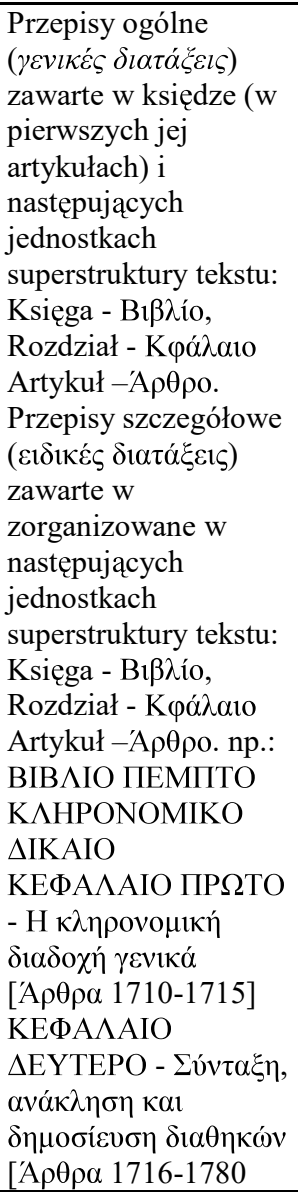 & 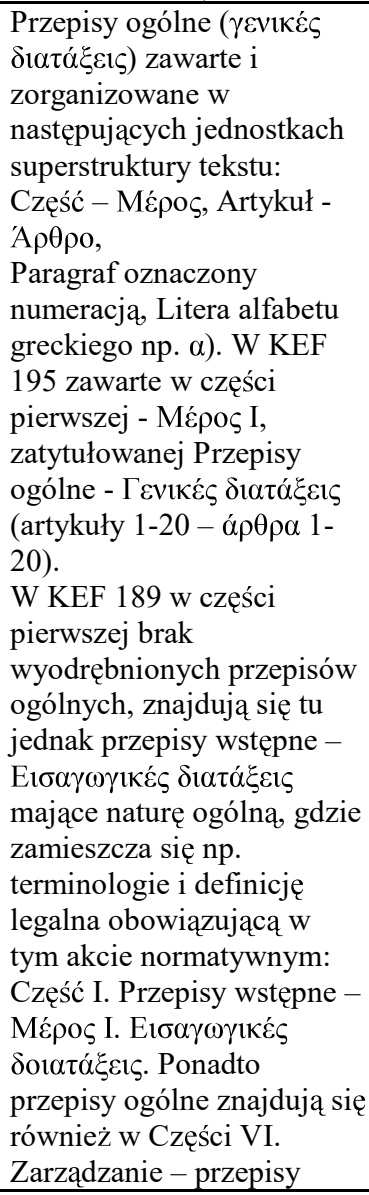 \\
\hline
\end{tabular}




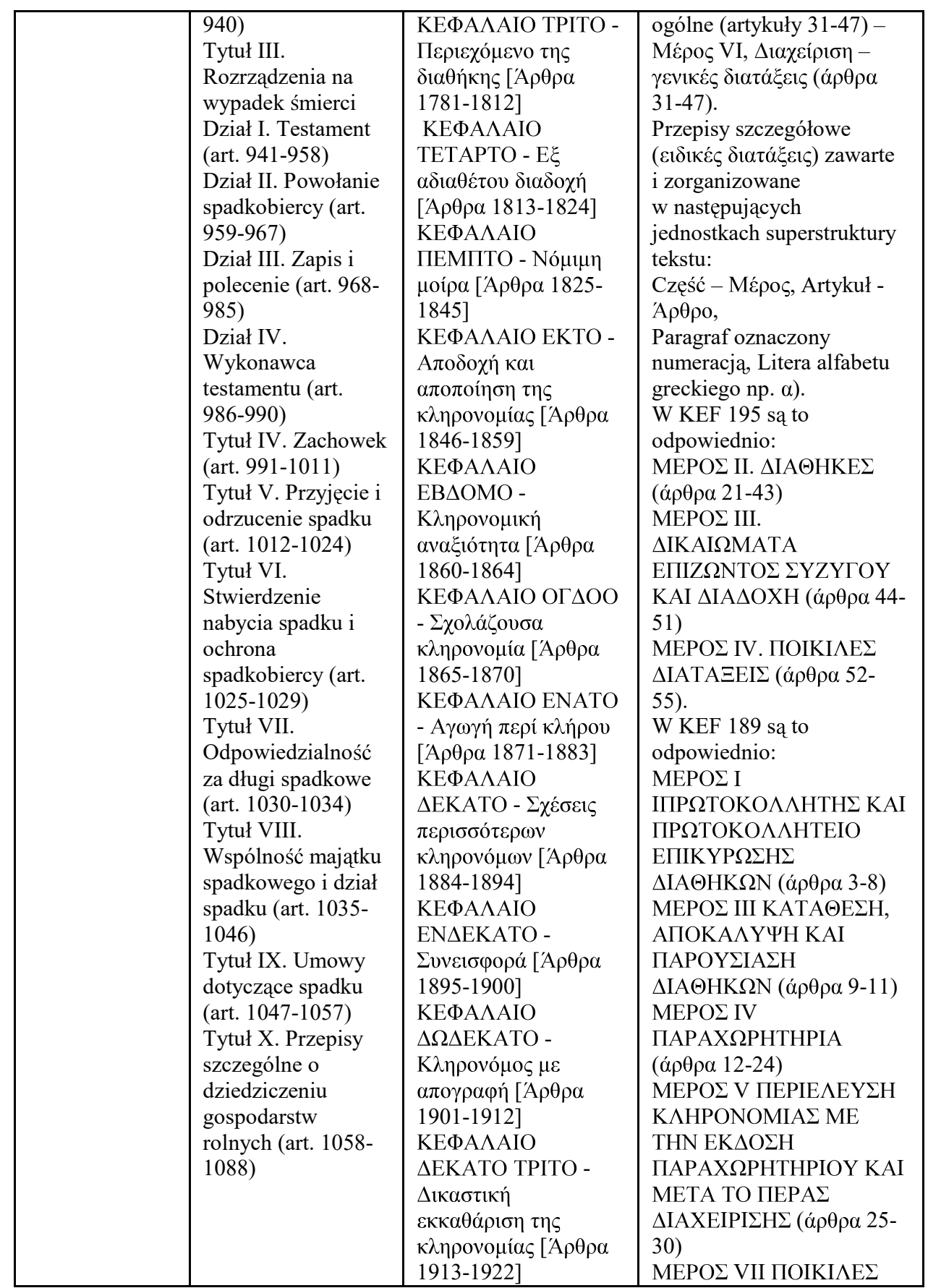


Karolina GORTYCH-MICHALAK, Super-I Makrostruktura polskich, greckich...

\begin{tabular}{|c|c|c|c|}
\hline & & 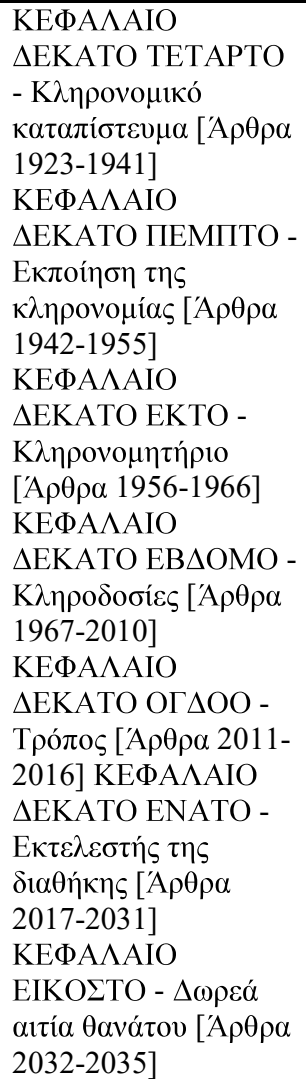 & $\Delta \mathrm{IATA} \Xi \mathrm{EI} \Sigma(\dot{\alpha} \rho \theta \rho \alpha$ 51-59) \\
\hline $\begin{array}{l}\text { Przepisy o } \\
\text { zmianie } \\
\text { przepisów } \\
\text { obowiązujących }\end{array}$ & $\begin{array}{l}\text { Przepisy poza } \\
\text { tekstem kodeksu } \\
\text { cywilnegg }^{66}\end{array}$ & $\begin{array}{l}\text { Przepisy poza tekstem } \\
\text { kodeksu cywilnego }{ }^{67}\end{array}$ & 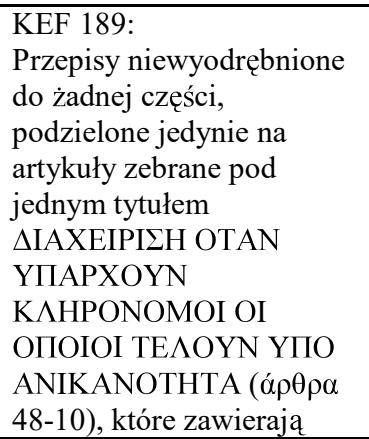 \\
\hline
\end{tabular}

${ }^{66}$ Zmiany w polskim Kodeksie Cywilnym są wprowadzane na mocy innych ustaw. Ostatnie akty normatywne zmieniające Kodeks cywilny to Ustawy z roku 2011: Ustawa z dnia 16 września 2011 r. o timeshare i Ustawa $\mathrm{z}$ dnia 18 marca 2011 r. o zmianie ustawy - Kodeks cywilny oraz niektórych innych ustaw.

67 Zmiany w GrKC wprowadza odrębna ustawa, która towarzyszy GrKC w wydaniach

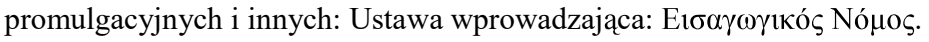


Comparative Legilinguistics vol. 14/2013

\begin{tabular}{|c|c|c|c|}
\hline & & & $\begin{array}{l}\text { informacje o zmianie } \\
\text { przepisów obowiązujących. }\end{array}$ \\
\hline $\begin{array}{l}\text { Przepisy } \\
\text { przejściowe i } \\
\text { dostosowujące }\end{array}$ & Jak wyżej. & Jak wyżej. & \\
\hline $\begin{array}{l}\text { Przepisy } \\
\text { uchylające, } \\
\text { przepisy o } \\
\text { wejściu ustawy } \\
\text { w życie oraz } \\
\text { przepisy o } \\
\text { wygaśnięciu } \\
\text { mocy } \\
\text { obowiązującej } \\
\text { ustawy } \\
\text { (przepisy } \\
\text { końcowe) } \\
\end{array}$ & Jak wyżej. & Jak wyżej. & 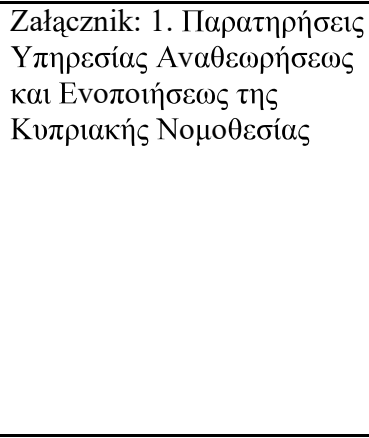 \\
\hline Załączniki & & & 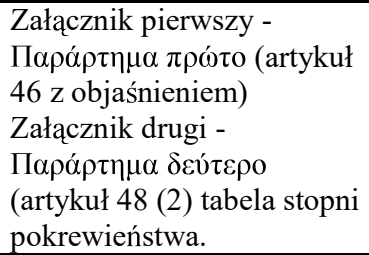 \\
\hline
\end{tabular}

\section{c) Wnioski}

1. Analiza na poziomie makrostruktury wskazuje różnice i podobieństwa w logicznym układzie tekstu. Wskazuje miejsca wspólne lub ich braki oraz lokalizuje je. Dzięki temu w perspektywie dalszych badań kontrastywnych powyższych tekstów w aspekcie translatologicznym rysuje się możliwość wyłonienia wielu ekwiwalentów translacyjnych na poziomie zdań, syntagm, fraz i wyrazów (por. Tab. 4 wiersz Przepisy ogólne i szczególowe). Przywołany w nawiasie przypadek otwiera pole do dalszych badań na niższych poziomach struktury, np. porównanie definicji legalnych prowadzi do uzyskania ekwiwalentów translacyjnych (Gortych-Michalak 2010: 200-201).

2. Analiza na poziomie makrostruktury wskazuje lokalizację na mapie aktu normatywnego poszczególnych elementów makrostruktury. Znajomość planu logicznego aktu normatywnego właściwego dla danego systemu prawnego zwiększa perspektywę badawczą analizy porównawczej tekstów. Uzasadnia dokonanie wyboru tekstów paralelnych mających inne cechy wspólne, np. inna gałąź prawa, jaką jest prawo międzynarodowe (po zawartość załączników Konstytucji Republiki Cypru, Tab. 3, wiersz Załaczniki).

3. Różny stopień kodyfikacji aktów normatywnych w Polsce, Grecji i na Cyprze, wynikający $\mathrm{z}$ panujących $\mathrm{w}$ tych państwa systemów prawnych, jaki jest widoczny szczególnie w tabeli 4 powyżej, w aspekcie translatologicznynm uzasadnia użycie różnych technik zapewniania ekwiwalencji w procesie przekładu, np. wykorzystanie 


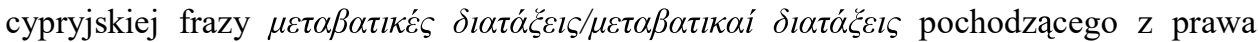
konstytucyjnego na potrzeby zapewnienia ekwiwalentu dla polskiej frazy przepisy przejściowe pochodzącego z prawa cywilnego.

\section{Podsumowanie badań}

Na podstawie przeprowadzonych badań można stwierdzić, iż przeprowadzenie analizy porównawczej tekstów aktów normatywnych na poziomie ich superstruktury i makrostruktury jest $\mathrm{w}$ aspekcie translatologii legilingwistycznej wartościową metoda służącą zapewnianiu ekwiwalentów translacyjnych. Metoda ta jest szczególnie użyteczna w sytuacji, kiedy w różnojęzycznych tekstach paralelnych nie istnieją konotaty. Wówczas prowadzenie badań porównawczych tekstów mających paralelne cechy i funkcje może dostarczyć adekwatne rozwiązania translatorskie.

Powyższe badania zostały przeprowadzone w kilu fazach, które uporządkowane tworzą następujący model badań:

1. Porównanie systemów i kultur prawnych - poznanie źródeł prawa.

2. Określenie cech paralelnych dla tekstów.

3. Wybór tekstów paralelnych mających cechy paralelne.

4. Analiza porównawcza tekstów paralelnych spełniających powyższe wymogi na poziomie superstruktury i makrostruktury (pojęcia łączące się ze sobą (por. van Dijk 1980, 127).

5. Zestawienie cech wspólnych i różnic porównywanych tekstów.

6. Wyłonienie ekwiwalentnych jednostek języka w celu stworzenia rozwiązań translatorskich np. zapewniania ekwiwalencji.

7. Określenie dalszych perspektyw badawczych np. dla innych korpusów tekstów paralelnych lub innych poziomów struktury tekstu.

\section{Zakończenie}

Celem niniejszego opracowania była analiza porównawcza tekstów cypryjskich, greckich i polskich aktów normatywnych na poziomie ich superstruktury i makrostruktury. Otrzymane wyniki badań potwierdzają ogólnie przyjęte w teorii przekładu twierdzenie o wysokiej wartości badan porównawczych a w szczególności badań tekstów paralelnych.

Zadowalające wyniki przeprowadzonego badania dają podstawy do dalszego rozwoju analogicznych badań porównawczych na innych korpusach tekstowych oraz z perspektywy innych elementów struktury tekstowej w aspekcie translatologicznym. 


\section{Bibliografia}

Crystal, David. 2008. A Dictionary of Linguistics and Phonetics. Sixth Edition, Malden USA: Blackwell Publishing.

Delisle, Jean et al., red. 1999. Translation terminology, Amsterdam: John Benjamins Publishing Company.

van Dijk, Teun, A...1980. MACROSTRUCTURES. An Interdisciplinary Study of Global Structures in Discourse, Interaction, and Cognition, Hillsdale, New Jersey: LAWRENCE ERLBAUM ASSOCIATES PUBLISHERS.

Fefes, Michalis, V. 200 Eisagogi sto dikaio. Syntagmatiko. Dioikitiko. Poiniko. Astiko. Emporiko. Ergatiko, Athina: Nomiki Vibbliothiki.

Fisiak, Jacek. 1981. Language and languages; Contrastive linguistics; Study and teaching, Oxford and New York: Pergamon.

Gortych, Karolina, Matulewskam Aleksandra. 2009. Translacyjne problem wyrażania modalności deontycznej w tekstach aktów normatywnych w języku angielskim, greckim i polski [W:] Prawo i język, red. Mróz Anna, Niewiadomski Adam, Pawelec Monika, 65-78. Warszawa: Zakład Graficzny Uniwersytetu Warszawskiego.

Gortych-Michalak, Karolina. 2010. Definicja legalna w polskich, greckich i cypryjskich aktach normatywnych $\mathrm{w}$ aspekcie przekładu prawniczego grecko-polskiego. [W:] Lingua Iuris: red. Mróz Anna, Niewiadomski Adam, 167-201. Warszawa: Zakład Graficzny Uniwersytetu Warszawskiego.

Grzybek, Joanna. 2009. Jezyk prawa cywilnego w aspekcie translatologicznym chińsko-polskim i polsko-chińskim, niepublikowana rozprawa doktorska, Poznań, UAM.

Hoey, Michael i Haughton. Diane. 2001. Contrastive analysis and translation. [W:] Routledge Encyclopedia of Translation Studies, red. Bake Mona, 45-49. London and New York: Rotledge.

Jopek-Bosiacka, Anna. 2006, Przektad prawny i sqdowy, Warszawa: PWN.

Kaczmarek Karolina. 2011. Lingua legis w aspekcie translatologicznym węgiersko-polskim i polsko-węgierskim, Legilingwistyka porównawcza, Tom 6/2011, Poznań: UAM, 1230.

Kielar, Barbara, Z. 1988. Ttumaczenie i koncepcje translatoryczne, Wrocław: Ossolineum.

Kierzkowska, Danuta. 2008. Ttumaczenie prawnicze, Warszawa: Translegis.

Korycki, Stefan, Kuciński, Jerzy, Trzciński Zenon, Zaborowski Jerzy. 2006. Zarys prawa, Warszawa: Lexis Nexis.

Krzeszowski, Tomasz P. 1990. Contrasting languages. The Scope of Contrastive Linguistics, Berlin, New York: Mounton de Gruyter.

Kubacki, Artur Dariusz, 2007, Problemy thumaczenia niemieckojęzycznych dokumentów samochodowych. Wspótczesne kierunki analiz przekładowych, pod red. Marii Piotrowskiej, seria Język a komunikacja 18, Kraków: Wydawnictwo Tertium, 121-132.

Kurtes, Svetlana. 2006. Contrastive Analysis at work: theoretical considerations and their practical application.SIGNUM: Estud. Ling, n. 9/1, jun. 2006, Londyn, 111-140.

Lizisowa, Maria, Teresa. 2006. Tekst - Kontekst - Interpretacja, W poszukiwaniu semiotycznodyskursywnych wzorców konkretyzacji języka, Kraków: Collegium Colimbinum.

Lizisowa, Maria, Teresa, 2009. Performatywne wypowiedzi prawne w aspekcie lingwistyki tekstu [W:] Prawo i język red. Mróz Anna, Niewiadomski Adam, Pawelec Monika, 19-36. Warszawa: Zakład Graficzny Uniwersytetu Warszawskiego.

Malinowski, Andrzej. 2006. Polski język prawny, Wybrane zagadnienia, Warszawa: Lexis Nexis.

Matulewska, Aleksandra. 2007. Lingua Legis in Translation, Amsterdam: Peter Lang Publishing House. 
Matulewska, Aleksandra. 2010. Teksty paralelne a ustalanie konotatów i denotatów na potrzeby przekładu polsko-angielskiego. Legilingwistyka porównawcza, Tom 3/2010, Poznań: UAM, 57-69.

Moser, Amalia, i Panaretou, Eleni. 2009. Tense, aspect and modality in legal texts. Proceedings of the 8th International Conference on Greek Linguistics, 1013-1026, http://www. linguist-uoi.gr/cd_web/case3.html (dostęp 10 grudnia 2011 godz. 12.00)

Neocleous, Andreas. 2000. Introduction to Cyprus Law, Limassol: Yorkhill Law Publishing.

Pieńkos, Jerzy. 1999. Podstawy juryslingwistyki. Język w prawie - Prawo w języku, Warszawa: MUZA SA.

Redelbach, Andrzej. 1996. Wstep do prawoznawstwa, Poznań: Ars Boni et Aequi.

Supreme Court of Cyprus, 2007-2013, Legal system, http://www. supremecourt. gov. cy/judicial/sc. nsf/DMLLegSystem_en/DMLLegSystem_en?OpenDocument (dostęp 20 grudnia godz. 16. 04).

Vlachopoulos, Stefanos. 2008. Translating into New LSP. Translation of laws in the Republic of Cyprus. Target 20, Amsterdam: John Benjamins Publishing Company, 103-11

Vermeer, Hans J. 2003. Skopos and Commission. W: The Translation Studies Reader, red. Venuti Lawrence, Baker Mona, 221-232. London and New York: Routledge.

Wronkowsk,a Sławomira i Zieliński Maciej. 1997. Zasady techniki prawodawczej, Warszawa: Wydawnictwo Sejmowe.

Wronkowska, Sławomira, Ziembiński, Zygmunt. 1997, Zarys teorii prawa, Poznań: Ars Boni et Aequi.

Zieliński, Maciej, 1999. Języki prawne i prawnicze. [W:] Polszczyzna 2000. Orędzie o stanie języka na przetomie tysiacleci red. Pisarek, 50-7 Kraków: Ośrodek Badań Prasoznawczych. Uniwersytet Jagielloński.

\section{Teksty źródłowe}

Konstytucja Rzeczpospolitej Polskiej w brzmieniu obowiązującym dnia 20. 12. 12.

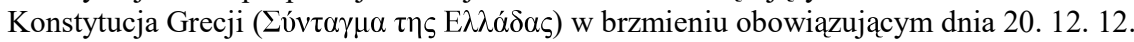

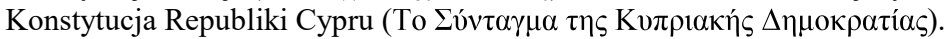

Polski Kodeks Cywilny w brzmieniu obowiązującym dnia 20. 12. 12.

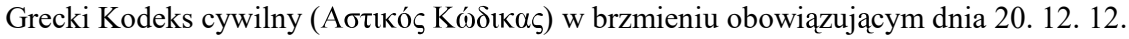

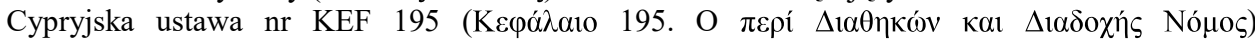
w brzmieniu obowiązujacym dnia 20.12.12.

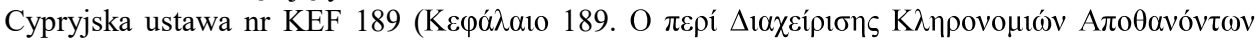
Nó ${ }^{\circ}$ ) w brzmieniu obowiązującym dnia 20. 12. 12. 
